\title{
THE PRESENT DAY RELEVANCE OF EKPE SOCIETY/MASQUERADE TO THE EFIKS OF NIGERIA
}

\author{
Offiong Offiong Asuquo ${ }^{1}$ \\ Department of Religious and Cultural Studies, \\ University of Calabar, Cross River State, Nigeria. \\ offiongasuquo2019@gmail.com²
}

\begin{abstract}
The Efiks have a lot of traditional plays and masquerades. Among them are Ekpe, Ukwa, Nnabo, Ibom, Ibo, Abang, Okpo, Ofiom, Tinkoriko and Nnuk among others. The origin of most of them are obscure, but they are all colourful masquerades which often display and entertain at festive and important occasions. Some of them are associated with cults or societies which play important roles in the community. They include Ekpe, Ukwa and Nnabo. This paper examines the meaning of Ekpe play and society, its history and background, its past role in the community, and its relevance and present day role in the society.
\end{abstract}

Keywords: Efik, Ekpe, masquerade, Nigeria.

\section{INTRODUCTION}

The Efiks are located located in the Old Calabar Oil Rivers region in the southeastern corner of modern day Nigeria. The town lies approximately 30 miles inland from the Atlantic Ocean, nestled on a narrow ridge in the deltaic zone of the Cross, Calabar, and Great Kwa Rivers. It is surrounded primarily by brackish water, mangrove swamps, and rain forest. The name Calabar is thought to come from the Portuguese word calabarra, meaning "the bar is silent," (Williams 2009) and perhaps describing the calm waters of the town's anchorage. The majority of its inhabitants are Efik, an ethnic group closely related to the surrounding Ibibio peoples. There are also small minorities of Efut and Qua, but the majority speaks Efik, a language classified under the Benue-Congo branch of the Niger-Congo family (Cook 2002).

Prior to the rise of European trade in the region, particularly the slave trade, the Efik were known for their prawn fisheries at the mouth of the Cross River. By the beginning of the 18th century, however, Calabar, due to "a favorable anchorage for European ships," (Simmons 1956: 22) had become "regional market center and nexus of overseas trade" (Simmons 1955: 62). The slave trade between Efik merchants and European ship captains grew steadily from the 1630s on and, by 1720, the major merchant families of Old Calabar had begun "to monopolize commerce in the Lower Cross River region" (Simmons 2018).

\section{Sociopolitical \& Economic Institutions of the Efik}

Efik had two separate, seemingly competitive sociopolitical structures, a traditional lineage-based system stressing ward autonomy and a unifying political system dominated by the Ekpe society. In terms of the former, the Efik community was divided into towns, wards, and ward sections, or family compounds. According to the pioneering ethnographic work of G.I. Jones, the early inhabitants of Calabar had no traditional sovereign authority and, as such, the local wards and settlements were semi-autonomous units initially bound together only by common customs, interests, and rituals (Enor et al., 2019). The early sociopolitical organization of Calabar was based on kinship and economic ties. The towns that collectively made up Calabar were broken down into semiautonomous units known as 


\section{Jurnal Sosialisasi \\ Jurnal Hasil Pemikiran, Penelitian, dan Pengembangan \\ Keilmuan Sosiologi Pendidikan \\ Vol 7, JNomor 2, Jufi 2020}

"houses," "wards" or, in terms of kinship, "maximal lineages." The Efik used the term ufok to describe these agnatic social units. The maximal lineage making up each ward would have a head and a council composed of the sublineage heads and other influencial householders. The lineage heads and councils would deal primarily with the external relations of the wards. They would rarely interfere in the lineage group's internal affairs, unless called upon by disputants to resolve a conflict through arbitration. The lack of a traditional authoritative body within the maximal lineages and within the Calabar community as a whole was offset by the necessity of projecting a "united front" to other wards within the community, which was often enough to guarantee the cooperation of its component parts.

By the beginning of the 17th century, and possibly as early as the mid-16th century, five "founding fathers" comprising two main lineage groups, Ema and Efiom Ekpo, had established the original Efik settlement at Creek Town (Ikot Etunko). These two lineage groups expanded and subdivided throughout the next century, with the establishment of new sublineages often corresponding to disputes within the original group and the founding of new settlements. The settlements of Old Town and Duke Town are linked to the advent of new lineage groups (Ita \& Bassey 2014; Yta 2015). Latham has recognized the existence of seven lineage segments, or wards, by the mid-18th century, six subdivisions of the two original groups and one ward established by a non-Efik "outsider" and freed slave, Eyo Nsa (Willy Honesty). Within the traditional sociopolitical structure of Efik society, there were several positions of influence, often held by the heads of the most powerful wards. Despite the European traders' use of the terms "king" and "duke" to describe the holders of these offices, they did not have sovereign powers and did not represent, by means of their title alone, a central authority in Efik society (Eyo 2019). Behrendt, Latham, and Northrup recognize the existence of three distinct "kingships" in Old Calabar during the late-18th century (Morrill 1963). They reference, and appear to validate, the observations of John Ashley Hall, a British sailor who visited Old Calabar in 1775, and who wrote of the division of political power into these three offices: the obong, or head of the civil government; the eyamba, or head of the legal system and president of the Ekpe society; and "King Calabar," or Oku Ndem Efik, who was the religious head as the leader of the town's cult of Ndem Efik, a water-based spirit that was the "tutelary deity at Old Calabar". The obong, as head of the civil government, did not possess sovereign powers but functioned as the chair of the village council, as well as the primary contact between the Efik and foreign traders The Oku Ndem Efik, as head of the once powerful "fishing cult," had no political authority and the office declined in influence during the 18th century, as the economic activity of Old Calabar shifted away from fishing towards the slave trade (Udoh 2017; Udoh 2018: Duke 2018). By the mid-19th century, the Ndem priest had been banned from trading with Europeans and the missionary Hope Waddell noted that only the holder of the office in 1847 was an impoverished old man who often had to beg for his dinner (Asuquo 2018).

This decline in the influence of the Oku Ndem Efik mirrored the increase in the influence of the eyamba, as the Ekpe society became the primary authority in Old Calabar during the slave-trade era. The transformation of the religio-cultural institution of Ekpe into a political institution provided the Efik with the nearest thing they had to a centralized authority. The Ekpe society of Old Calabar seems to have emerged, or at least transformed into its political form, during the 18th century, most likely due to the spread of trade with Europeans in slaves and, later, palm oil. The significant increase in the wealth of a small percentage of Old Calabar's merchants led to new patterns of Efik stratification. Along with this increase in wealth, the growing division between the wealthy and poor, and the constant presence of European ships anchored in the Cross River, there came a need for a more effective means of regulating economic activity, interactions with the Europeans, as well as, to a lesser extent, the social behavior of the inhabitants of Old Calabar. The Ekpe society had become, by the time Antera Duke began his diary in 1785, the Efik's primary socio-political institution. Although Ekpe eventually developed into a quasi-governmental institution, the society's foundations were decidedly religious. 


\section{Jurnal Sosialisasi \\ Jurnal Hasil Pemikiran, Penelitian, dan Pengembangan \\ Keilmuan Sosiologi Pendidikan \\ Vol 7, JNomor 2, Jufi 2020}

\section{The Meaning of Ekpe Traditional Play/Society}

The word "Ekpe" is an Efik word which is used to refer to various big wild animals of the cat family. These include the Lion, Leopard, Tiger, Cheetah and the Lynx. This word is the name given to the most popular and important traditional play of the Efiks. It is not quite known why the masquerade should be associated with these wild animals by adopting their name 'Ekpe'. Perhaps, it could be due to the authority, power, reverence and fear which these wild animals elicit from other creatures including man. By adopting the name of the lion or leopard, the masquerade would appear to possess a similar power, authority and awe like the wild animals of the same name. The adoption of the name by the masquerade and its society could be due to the desire of identifying with the power of the beast, and to indicate that they do possess supernatural power which enabled them to exercise authority over other aspects of the society.

\section{History and Background of the Ekpe Society/Masquerade}

The Ekpe masquerade otherwise known as the Idem Ikwo, is one of the visible representation or expressions of the Ekpe society or cult (Aye 70). Some Efik traditionalists have claimed that Ekpe is indigenous to and originates from Efik land, but some authorities have shown that it was actually obtained from outsiders. Eyo Okon Akak citing A. K. Hart, states that it originated from the secret cult 'Nyana - Yaku' which was based on the worship of the Sylvan deity (288). But this was not the original Ekpe which we have today because he further adds that one Asibong Ekondo and his wife Mutaka who were Efut people from Usak Edet, bought and sold the secrets of the five small Ekpe grades to the Efiks at Creek Town during the reign of Eyo Ema Atai (288). He further postulates that this same Usak Edet man later on sold the remaining Ekpe grades to Oku Atai the cousin of King Eyo Ema Atai, and later on, the king himself also handed over the other five small grades he had purchased earlier to this same Oku Atai (288). Thus the Efiks acquired the cult fully.

Aye corroborates this assertion by stating that the Efiks purchased Ekpe from some Ekoi people who came from Usak Edet (70). However, he does not elaborate on this. This appears to dovetail into Akak"s assertion, because the Ekoi people from Usak Edet referred to by Aye, could be the Asibong Ekondo and his wife Mutaka who were Efuts from Usak Edet according to Akak. This implies that both scholars agree that some fellows from Usak Edet, whether Efuts or Ekois, sold the secrets of the Ekpe society to the Efiks. This also implies that Ekpe did not originate from the Efiks, but was obtained from outsiders, after which it was adapted to suit the Efik traditional society and needs.

\section{The Role of the Ekpe in the Past}

Ekpe society acted as the custodian, guardian and protector of the moral fabric of the Efik society. It served to encourage and protect right conduct in the Efik community. It also instilled some moral traits in its members or initiates. As a custodian of the moral standards of the Efik society, Ekpe served to protect, preserve and encourage those actions which were considered good, right and desirable by all. It carried out these functions in various aspects of societal life such as: political, economic, social, cultural and religious.

Politically, it represented the Efik's highest institution of government, having in the past, the supreme power of life and death. Nobody or group could ever challenge any decision of the society which often settled major disputes between individuals or groups, and cases between one Efik clan and the other. As a one party system of government, its judgement was always final, and was not subject to appeal. These legislative and judicial functions were derived from the political control of the Ekpe cult over the people and the society. The disputes, and violent conflicts which the Ekpe settled could be classified as immoral and undesirable acts, by settling them, Ekpe was trying to preserve the moral standards of the society.

Economically, it provided revenues to members who normally benefited from the entrance and initiation fees paid by new members. Fines from members and non-members, as well as gifts from many other sources were also shared among members according to their grades and titles. 


\section{Jurnal Sosialisasi \\ Jurnal Hasil Pemikiran, Penelitian, dan Pengembangan \\ Keilmuan Sosiologi Pendidikan \\ Vol 7, JNomor 2, Jufi 2020}

Through this, the society realized much money from wealthy European traders who accepted membership in order to protect the interest of their business. Membership gave them the right of recovering their debts more easily through the society (Akak 292). In these ways, Ekpe enriched the resources of some of its members and enhanced or improved the businesses of others.

Socially, Ekpe, as the supreme authority, helped the weak and the poor to overcome oppression and injustice, because they had equal rights to present their cases to the society. Members endeavoured to keep clean records so as to be promoted to higher grades. Furthermore, the society also brought all Efik communities together under one supreme authority.

The social impact was also seen in the numerous ceremonies and celebrations with sumptuous feastings, singing, dancing and merriments during initiation of new members, installation of title holders and funerals of dead members who were title holders (Akak 292). Through these ways, Ekpe provided entertainment and relaxation to members of the public, enhanced their wellbeing and the progress of the community.

As a law enforcing cult with legislative and judicial powers, it made several laws, for instance it abolished the practice of human sacrifice at the funerals of Efik nobles. It also abolished the holding of markets on Sundays and ended the practice of witch-hunting through the administration of 'esere beans' to suspects.

Religiously, members swore by Ekpe, made promises by it and consulted it when faced with difficulties. Its oath or 'mbiam ekpe' was believed to be very strong and effective, and capable of preventing crimes and offences. The effect of this oath on any culprit was sudden death by swelling (Akak 292).

\section{The Present Day Relevance and Role of the Ekpe Society}

Ekpe has passed through centuries of supreme authority into another century of power curtailment and a period of modesty as a result of various influences, especially external ones. Inspite of all these modifications, Ekpe still stands as a traditional institution which cannot be easily swept away (Akak 292).

In this vein, it is still performing some of the functions it performed in the past. Politically, most of its powers have been eroded as it is no longer the Efik highest institution of government, neither does it have the supreme power of life and death as it did in the past. Nevertheless, it is still closely associated with the Efik throne. The Efik king is expected to be an Ekpe initiate of a high rank. Certain traditional ceremonies and rites are performed at the Ekpe shrine or shed during the coronation of a new king. The Ekpe masquerade (Idem Ikwo), still symbolizes the authority within the Efik throne. It is included in emblems, symbols and insignias of various traditional Efik organisations.

The close association or linkage of the Ekpe with the Efik throne, preserves the impression that the past authority of Ekpe is still behind the throne, although this may not be completely correct. This impression serves to instill or command awe and respect from the Efiks for the Efik throne. They obey rules and orders from the king. For instance, the king can ban or prevent a recalcitrant masquerade from displaying. The king still settles disputes between contending parties. Thus the authority of Ekpe still exists through the Efik throne from where it is still trying to preserve and maintain moral standards.

Economically, it is still providing resources to its members, though on a smaller scale. Initiation fees from new members, fines from members and non-members as well as gifts from other sources are still being shared among members according to their grades. Socially, Ekpe enhances good conduct among its members, as there are rules and regulations for them. They endeavor to behave well so as to ascend to higher Ekpe grades. Any erring initiate can be fined drastically. Similarly, any erring Ekpe masquerade can be fined or disciplined in other ways.

Religiously, some initiates still revere and swear by Ekpe. This brings us to the issue of 'Mbiam Ekpe' (oath) which is still relevant today. It is a vital and potent factor in the administration of justice and law by Ekpe. It is a sort of juju, charm or fetish material which is believed to have power to harm trespassers. Occasionally, it is used by 
communities to prevent trespassers from disputed lands. It is also used to protect properties from thieves. When placed in an area, it means that nobody should trespass into that area until it is removed. Till today, 'Mbiam' is still being used in various Efik communities to settle or manage land disputes. It checks land disputes by preventing the warring parties from entering there, and it also protects properties and premises from intruders.

\section{CONCLUSION}

The foregoing has highlighted the importance and relevance of Ekpe in the traditional affairs of the Efik people of Nigeria. The Ekpe masquerade is the visible representation or expression of the society. The Ekpe society has proved to be a custodian and enforcer of traditional laws and order both in the past and present. Though its present influence has diminished as compared with the past, Efiks still revere, fear and respect Ekpe. They are afraid to violate any Ekpe laws or prohibitions via 'Mbiam Ekpe'. Even the mere sight of the Ekpe masquerade, elicits awe, fear, respect and admiration from onlookers, while some people often run away from such masquerades so as not to be flogged. So the Ekpe is still remarkable and relevant to the traditional, social and moral life of the community. In view of the foregoing, it is hereby recommended that the Ekpe society should be revived and encouraged by the government.

The security and law enforcement agencies should liase with the society and try to tap from their law enforcement abilities. Ekpe should be integrated into and made to play a more prominent part in the tourism industry. This could be done through regular festival displays, Ekpe exhibitions and sales of Ekpe related souvenirs. Scholars and citizens should explore more ways in which Ekpe can be made to be more useful and beneficial to the present day society. The results of such researchers should be publicized and properly utilized by the relevant authorities.

\section{REFERENCES}

Akak, E. O. Efiks of Old Calabr vol, iii, Culture and Superstutions. Calabar: Akak and Sons, 1982.

Asuquo, O. O. (2018). Religious conflicts and violence in Nigeria: the way out. Sophia: An African Journal of Philosophy, 18(2), 80-83.

Aye, E. U. Old Calabar through the Centuries. Calabar: Howard Press, 1967

Cook, T. L. (2002). Focus in Efik. Journal of African Languages and Linguistics, 23(2), 113-152. https://doi.org/10.1515/jall.2002.009

Duke, E. O. (2018). Christian Military Chaplains'role and the Gospel of Non-Violence and Mutual Co-Existence in Contemporary Nigerian Society: An Ethical Study. Journal of Inculturation Theology 15(2), 258-271.

Duke, E. O., \& Okafor, J. O. (2020). Poverty Alleviation Policies of Selected Churches in Anambra State, Nigeria. GNOSI: An Interdisciplinary Journal of Human Theory and Praxis, 3(1), 4052.

Enor, F. N., Edet, A. S., \& Etim, A. E. (2019). Archaeology, History and the Monoliths Heritage: Nta Akwansisi in Perspective. Academic Journal of Interdisciplinary Studies, 8(3), 248-248.

Eyo, U. E. (2019). Between Religion and Agriculture: A Roadmap to Revamping Nigeria's Economy. GNOSI: An Interdisciplinary Journal of Human Theory and Praxis, 2(1), 62-70.

Hart, A. K. Report of Enquiry into the Dispute over the Obongship of Calabar. Enugu: Government Printers, 1964 
Ita, E. O., \& Bassey, O. Imaginative story writing: An effective tool in the acquisition and use of English language skills among school children in Cross River State, Nigeria. International Journal of Liberal Arts and Social Science 2 (9).

Morrill, W. T. (1963). The Ibo in Twentieth Century Calabar. Comparative Studies in Society and History, 5(4), 424-448. https://doi.org/10.1017/S0010417500001845

Omoregbe, J. Ethics, A Systematic and Historical Study. London: Global Educational Services, 1979.

Simmons, D. (2018). An Ethnographic Sketch Of The Efik People. In Efik Traders of Old Calabar (pp. 1-26). https://doi.org/10.4324/9780429504280-1

Simmons, D. C. (1955). Specimens of Efik Folklore. Folklore, 66(4), 417-424. https://doi.org/10.1080/0015587X.1955.9717505

Simmons, D. C. (1956). Efik Divination, Ordeals, and Omens. Southwestern Journal of Anthropology, 12(2), 223-228. https://doi.org/10.1086/soutjanth.12.2.3629116

Udoh, E. W. (2017). A Comparative Examination of Issues of Religion and Culture in Africa. American Journal of Social Issues and Humanities, 7(1), 66-75

Udoh, E. W. (2017). The Problem of Evil: A Case Against the Omnipotence and The Goodness of God. Leajon: Academic Journal of Interdisciplinary Studies, 8(2), 66-83.

Udoh, E. W. (2018). The Religious Response to Migration and Refugee Crises in Cross River State, Nigeria. FAHSANU Journal, 1(2), 75-85.

Williams, U. E. (2009). Calabar, Nigeria. In Practical Neurology (Vol. 9, Issue 4, pp. 237-239). https://doi.org/10.1136/jnnp.2009.182436

Yta, E. M. (2015). The Arts Teacher: Enriching Pedagocy through Arts Based Instruction. A Journal of Theatre \& Media Studies 1 (1), 111-117. 